\title{
Morphology Category
}

National Cancer Institute

\section{Source}

National Cancer Institute. Morphology Category. NCI Thesaurus. Code C117608.

A classification of morphology data. 